JPPKMI 2 (2) (2021)
JURNAL PENELITIAN DAN PENGEMBANGAN
KESEHATAN MASYARAKAT INDONESIA
Jttps://journal.unnes.ac.id/sju/index.php/jppkmi

\title{
Perbedaan Antara Larutan Lidah Buaya dan Larutan Kunyit dalam Menurunkan Kadar Formalin pada Ikan Teri
}

\author{
Ashlikhatul Fuadah A1 Hasyim ${ }^{1} \bowtie$, Suratman $^{2}$, Dwi Sarwani Sri Rejeki ${ }^{2}$ \\ ${ }^{1}$ Mahasiswa Jurusan Kesehatan Masyarakat FIKes Universitas Jenderal Soedirman, Indonesia \\ ${ }^{2}$ Departemen Kesehatan Masyarakat FIKes Universitas Jenderal Soedirman, Indonesia
}

\section{Info Artikel Abstrak}

Sejarah Artikel:

Diterima Juni 2021

Disetujui Desember 2021

Dipublikasi Desember 2021

\section{Keywords:}

Formaldehyde, Anchovy,

Aloe vera, Turmeric

URL:

https://iournal.unnes.ac.i d/sju/index.php/ippkmi Larticle/view/47247

\begin{abstract}
Formalin telah disalahgunakan pada ikan teri untuk menghindari kerusakan. Lidah buaya dan kunyit memiliki kandungan saponin yang dapat menurunkan kadar formalin. Penelitian ini bertujuan untuk mengetahui perbedaan larutan lidah buaya dan kunyit dalam menurunkan kadar formalin pada ikan teri. Jenis penelitian ini adalah true experiment dengan menggunakan Postest only Control Group Design. Populasi dalam penelitian ini adalah ikan teri di Pasar Wage Banyumas. Penelitian ini menggunakan metode spektrofotometri dengan larutan lidah buaya dengan konsentrasi $60 \%, 80 \%, 100 \%$ dan larutan kunyit dengan konsentrasi $20 \%, 25 \%$, dan $30 \%$ dengan pengulangan sebanyak 4 kali. Ikan teri direndam pada masing-masing larutan, kemudian diuji kadar formalin. Uji statistik adalah uji normalitas dengan Shapiro wilk, dilanjut dengan uji Kruskal wallis, dan uji Mann whitney. Hasil penelitian menunjukkan bahwa terdapat perbedaan yang nyata penurunan kadar formalin antara kelompok kontrol dan kelompok perlakuan. Hal ini disebabkan karena adanya kandungan saponin pada larutan lidah buaya dan larutan kunyit. Kadar formalin paling rendah terdapat pada larutan lidah buaya $80 \%$. Kadar formalin pada larutan lidah buaya lebih rendah dibandingkan kadar formalin pada larutan kunyit, yaitu larutan lidah buaya $80 \%$ sebesar 0,197 ppm. Larutan lidah buaya 80\% mempunyai kemampuan untuk menurunkan kadar formalin paling tinggi.
\end{abstract}

\begin{abstract}
Formaldehyde usage has been misused in anchovy to avoid the harm. Aloe vera and turmeric contain saponins which can reduce formaldehyde levels. This study aims to determine the differences in aloe vera solution and turmeric solution in reducing formaldehyde level in anchovy. This research is a true experimental research with Post-test only Control Group design. The population of this research is anchovy in the Wage Banyumas Market. This research uses spectrophotometry methods with aloe vera solution with concentration of $60 \%, 80 \%, 100 \%$ and turmeric solution with concentration of 20\%, 25\%, and 30\% 4 times repetition. Anchovy were soaked in each treatment, and then the formaldehyde level were tested. The statistical test is normality test with Shapiro wilk, continues with Kruskal wallis test and Mann whitney test. Result shows that the aloe vera solution and turmeric solution can lower the formaldehyde level significantly. This is due to the presence of saponins in the aloe vera solution and turmeric solution. The least formaldehyde level found in aloe vera solution with concentration of $80 \%$. The formaldehyde level in aloe vera solution is lower than the formaldehyde level in turmeric solution, there are aloe vera solution $80 \%$ is $0,197 \mathrm{ppm}$. The aloe vera solution with concentration of $80 \%$ has the ability to reduce the highest folmaldehyde level.
\end{abstract}

(C) 2021 Universitas Negeri Semarang

\footnotetext{
Alamat korespondensi:

J1. Dr. Soeparno Karangwangkal Purwokerto 53123 Gedung B

Jurusan Kesehatan Masyarakat Fakultas Ilmu-ilmu Kesehatan

Universitas Jenderal Soedirman

E-mail: ashlikhatul.fuadaah@gmail.com
} 


\section{PENDAHULUAN}

Formalin merupakan bahan beracun dan berbahaya bagi kesehatan manusia. Efek dari bahan makanan berformalin baru akan terasa beberapa tahun kemudian. Jika kandungannya dalam tubuh tinggi, bereaksi secara kimia dengan hampir semua zat didalam sel sehingga menekan fungsi sel dan menyebabkan kematian sel yang menyebabkan keracunan pada tubuh. Selain itu, kandungan formalin yang tinggi dalam tubuh juga menyebabkan iritasi lambung, alergi, bersifat karsinogenik menyebabkan kanker (Cahyadi, 2008). Di Indonesia, formalin menjadi salah satu penyebab kejadian luar biasa keracunan pangan dengan $1,7 \%$ dari total 175 artikel lengkap yang dianalisis mulai dari tahun 2000-2015 (Arisanti, 2018). Pada penelitian lain mengenai tren keracunan makanan di berbagai wilayah Indonesia Tahun 2014 dan 2015 menyatakan bahwa pada bulan April-Juni Tahun 2014 ada 1 insiden keracunan akibat bahan kimia dalam pengawetan ikan. Insiden keracunan kembali terjadi pada bulan JuliSeptember 2014, ada 1 insiden keracunan pangan akibat formalin dalam pengawetan ikan hasil tangkapan (Rhomadhoni, 2018).

Formalin ditemukan di beberapa bahan makanan seperti pada buah-buahan (Syahrizal, 2016), tahu (Ariani, 2016), ikan asin (Ane, 2016) dan ikan teri (Nurbaya, 2016). Studi pendahuluan yang dilakukan peneliti dengan mewawancarai petugas LOKA POM Banyumas Bapak Gaung Ranggatama Pengawas Farmasi dan Makanan Ahli Pertama menyatakan saat pemeriksaan makanan di Pasar Manis pada tanggal 21 Mei 20191 dari 32 sampel positif mengandung formalin. Hasil dari wawancara didapat bahwa bahan makanan berformalin yang ditemukan yaitu ikan teri.

Penurunan kadar formalin sangat diperlukan untuk dapat meminimalisir bahaya yang ditimbulkan oleh penggunaan formalin dalam makanan. Penelitian yang pernah dilakukan oleh Daniela (2019) menggunakan larutan lidah buaya untuk menurunkan kadar formalin dengan efektivitas paling baik ada pada konsentrasi $100 \%$ dan perendaman selama 90 menit dengan penurunan sebesar 58,64\%. Penelitian lain menyebutkan bahwa pemberian ekstrak lidah buaya dapat secara efektif menurunkan kadar formalin dalam ikan tongkol dengan konsentrasi minimal 50\% (Rullyansyah, 2020).

Pada penelitian oleh Berlian (2017) menyatakan bahwa larutan konsentrasi kunyit yang paling efektif dalam menurunkan kadar formalin pada tahu putih sebesar $20 \%$ dengan lama perendaman selama 90 menit sebesar $63 \%$. Namun hasil uji organoleptik pada penelitian tersebut menyatakan bahwa hasil perendaman tahu putih selama 90 menit menghasilkan tahu berwarna sangat kuning dan berbau kunyit menyengat. Saat ini, belum adanya penelitian yang membandingkan larutan lidah buaya dan larutan kunyit dalam penurunan kadar formalin. Berdasarkan hasil uraian tersebut peneliti ingin meneliti mengenai perbedaan antara larutan lidah buaya (Aloe vera) pada konsentrasi $60 \%$, $80 \%$ dan $100 \%$ dan kunyit (Curcuma longa) pada konsentrasi $20 \%, 25 \%$, dan $30 \%$ dengan lama perendaman 60 menit dalam menurunkan kadar formalin pada ikan teri

\section{METODE}

Penelitian dan uji formalin dilaksanakan pada Laboratorium Kimia, Fakultas Matematika dan Ilmu Pengetahuan Alam, Universitas Jenderal Soedirman Purwokerto. Penelitian ini dilaksanakan pada Juni 2020.

Alat yang digunakan timbangan, kompor, blender, toples, pisau, labu ukur, rak tabung reaksi, tabung reaksi, pipet tetes, saringan, saung tangan, pipet ukur, gelas arloji spektrofotometer, Gelas ukur 1 L, saringan, sarung tangan, dan alat tulis. Bahan yang digunakan dalam penelitian ini adalah sampel ikan teri, ammonium asetat, asam asetat, formalin $37 \%$ formaldehid dalam air, kunyit, lidah buaya, asetil aseton.

Prosedur kerja antara lain: 1) Pembuatan larutan Nash untuk analisis kadar formalin, 150 gram ammonium asetat dilarutkan dalam 700 ml. kemudian ditambahkan $3 \mathrm{ml}$ asam asetat glasial dan $2 \mathrm{ml}$ asam asetil aseton.aquades 
ditambahkan hingga volume menjadi $1000 \mathrm{ml}$. 2) Pembuatan larutan baku formalin $1000 \mathrm{ppm}$, larutan formalin $37 \%$ diambil $1 \mathrm{ml}$ diencerkan dengan aquades mencapai $370 \mathrm{ml} .3$ ) Pembuatan kurva kaliberasi, larutan baku formalin 1000 ppm diencerkan bertingkat hingga mencapai konsentrasi 0, 2, 4, 6, 8, 10, 14 ppm. Masingmasing larutan standar dipipet $5 \mathrm{ml}$ ditambahkan $5 \mathrm{ml}$ perekasi Nash dan $5 \mathrm{ml}$ aquades. Campuran dikocok dan dipanaskan $\left(40^{\circ} \mathrm{C}\right)$ selama 30 menit, dinginkan 30 menit. Serapan diukur pada panjang gelombang 412 nm.4) Pembuatan media control, Ikan teri diambil sebanyak 10 gram dihaluskan dan direndam dengan $50 \mathrm{ml}$ aquades sambil diaduk selama 5 menit dan disaring. Filtrate diambil sebanyak $1 \mathrm{ml}$ dimasukkan kedalam labu ukur $50 \mathrm{ml}$ dan volumenya dicukupkan. 5) Pembuatan larutan lidah buaya, lidah buaya dikupas kemudian diblender sebanyak 600 gram ditambah aquades sebanyak $400 \mathrm{ml}$ untuk $60 \%$, 800 gram ditambah aquades sebanyak $200 \mathrm{ml}$ untuk $80 \%$ dan 1000 gram untuk $100 \%$ tanpa penambahan aquades kemudian disaring. 6) Pembuatan Larutan Kunyit, kunyit dikupas kemudian diblender sebanyak 200 gram ditambah aquades sebanyak $800 \mathrm{ml}$ untuk $20 \%$, 250 gram ditambah aquades sebanyak $750 \mathrm{ml}$ untuk $25 \%$ dan 300 gram ditambah aquades sebanyak $700 \mathrm{ml}$ untuk 30\% kemudian disaring. 7) Perlakuan pada ikan teri berformalin dengan perendaman dengan larutan lidah buaya dan kunyit, larutan lidah buaya dan kunyit disiapkan pada gelas ukur atau toples sesuai konsentrasinya, kemudian sampel ikan teri dimasukan ke dalam gelas ukur atau toples dan direndam sesuai dengan waktu yang telah ditentukan. 8) Pengukuran formalin, ikan teri setelah perlakuan diambil sebanyak 10 gram dihaluskan dan direndam dengan $50 \mathrm{ml}$ aquades sambil diaduk selama 5 menit dan disaring. Filtrat diambil sebanyak $1 \mathrm{ml}$ dimasukkan kedalam labu ukur dan volumenya dicukupkan. Larutan sampel diambil sebanyak $5 \mathrm{ml}$ kemudian dimasukkan kedalam tabung reaksi. Pereaksi Nash ditambahkan sebanyak $5 \mathrm{ml}$ ke dalam tabung reaksi kemudian dipanaskan selama 30 menit pada suhu 40oC. Didinginkan selama 30 menit. Kemudian sampel diukur menggunakan spektrofotometer.

\section{HASIL DAN PEMBAHASAN}

Gambar 1 menunjukan bahwa rata-rata suhu larutan sebelum perlakuan relatif homogen dengan suhu $26,4^{\circ} \mathrm{C}$. Sedangkan rata-rata suhu larutan setelah perlakuan relatif heterogen dengan suhu paling tinggi sebesar $26,4^{\circ} \mathrm{C}$ dan terendah sebesar $26,1^{\circ} \mathrm{C}$.

Hasil Penelitian menunjukkan suhu larutan pada kelompok perlakuan maupun kontrol memperoleh hasil yang relatif homogen. Berdasarkan hasil pengukuran suhu baik sebelum dan sesudah perlakun berkisar

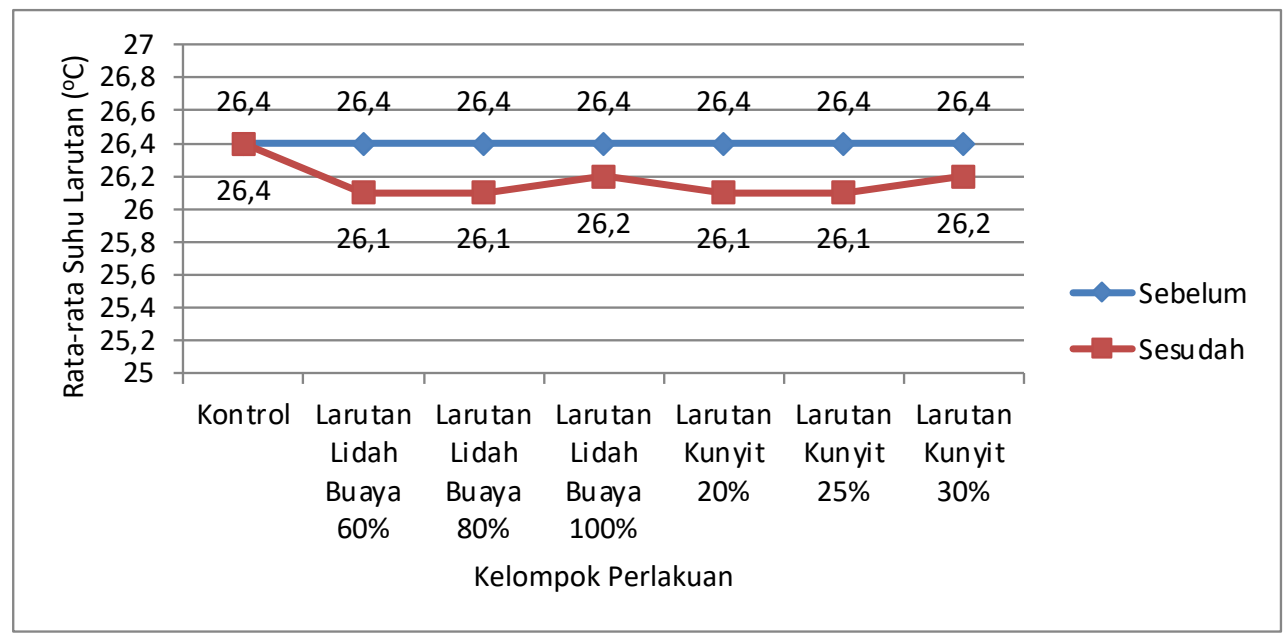

Gambar 1. Grafik rata-rata suhu larutan sebelum dan sesudah perlakuan 


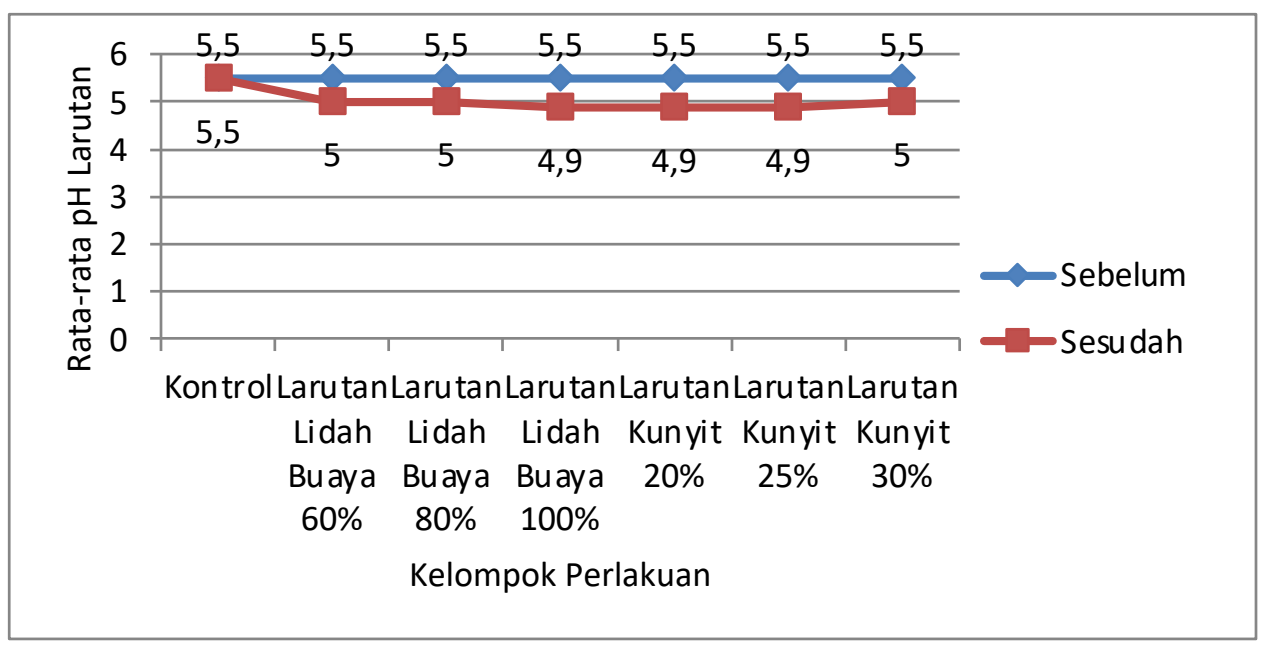

Gambar 2. Grafik rata-rata pH larutan sebelum dan sesudah perlakuan

$26,2-26,4^{\circ} \mathrm{C}$. Suhu dapat mempengaruhi laju reaksi dan menjadi salah satu faktor yang dapat mempengaruhi penurunan kadar formalin. Semakin tinggi suhu larutan dapat menurunkan kadar formalin lebih efektif. Hal ini terjadi karena ikatan antara protein dan formalin atau yang disebut senyawa methylene bisa terurai kembali menjadi protein dan formalin melalui reaksi hidrolisis. Namun reaksi ini tidak terjadi secara spontan karena reaktifitas ion $\mathrm{H}+$ dari air tidak reaktif terhadap senyawa methylene. Dengan demikian diperlukan adanya suatu tambahan energi yaitu berupa panas yang menyebabkan berkurang atau menghilangnya kandungan formalin (Purawisastra, 2011).

Rata-rata $\mathrm{pH}$ larutan dapat dilihat pada gambar 2 sebelum perlakuan relatif homogen dengan $\mathrm{pH}$ yaitu 5,5. Sedangkan pada pengukuran $\mathrm{pH}$ larutan setelah perlakuan didapatkan $\mathrm{pH}$ yang heterogen dengan $\mathrm{pH}$ terendah 4.9 dan yang tertinggi yaitu 5,5.

Hasil penelitian menunjukan $\mathrm{pH}$ pada larutan lidah buaya dan larutan kunyit relatif asam dengan $\mathrm{pH}$ sebesar 5,5. Hal ini dikarenakan lidah buaya mengandung vitamin $\mathrm{C}$ dan asam malat 817,8-3427,8 $\mathrm{mg} / 1$ sedangkan kunyit memiliki kandungan Vitamin $\mathrm{C}$ atau asam askorbat sebanyak $26 \mathrm{mg}$ setiap 100 gram rimpang kunyit. Penurunan $\mathrm{pH}$ larutan setelah perlakuan disebabkan karena formalin memiliki $\mathrm{pH}$ relatif rendah 2,8 - 4 sehingga dapat menurunkan $\mathrm{pH}$ ikan teri yang akan menurunkan $\mathrm{pH}$ larutan setelah perlakuan
Tabel 1. Hasil Pengukuran kadar formalin sesudah perlakuan

\begin{tabular}{ll}
\hline Perlakuan & $\begin{array}{l}\text { Rata-rata kadar } \\
\text { formalin (ppm) }\end{array}$ \\
\hline Kontrol lidah buaya 60\% & 2,533 \\
Larutan & 0,357 \\
Larutan lidah buaya 80\% & 0,197 \\
Larutan lidah buaya & \\
$100 \%$ & 0,434 \\
Larutan kunyit 20\% & 1,293 \\
Larutan kunyit 25\% & 1,215 \\
Larutan kunyit 30\% & 0,963 \\
\hline
\end{tabular}

(Daniela, 2019).

Tabel 1 menunjukkan bahwa pengukuran

kadar formalin sesudah perlakuan relatif heterogen. Pengukuran kadar formalin sesudah perlakuan tertinggi pada kelompok kontrol dengan rata-rata $2,533 \mathrm{ppm}$ dan terendah pada kelompok perlakuan larutan lidah buaya $80 \%$ dengan rata-rata $0,197 \mathrm{ppm}$.

Hasil penelitian menunjukkan rata-rata kadar formalin sebelum perlakuan atau pada kelompok kontrol sebesar 2,533 ppm. Rata-rata kadar formalin pada ikan teri dengan perlakuan perendaman dengan larutan lidah buaya menunjukkan bahwa kadar formalin paling rendah terdapat pada perlakuan dengan larutan lidah buaya $80 \%$ sebesar 0,197 ppm, diikuti dengan perlakuan larutan lidah buaya $60 \%$ sebesa $0,357 \mathrm{ppm}$, dan larutan lidah buaya $100 \%$ sebesar 0,434 ppm. Hasil tersebut menunjukkan adanya perlakuan perendaman dengan larutan lidah buaya dapat menurunkan 
hasil kadar formalin pada ikan teri dibandingkan dengan kontrol. Hasil penelitian ini sejalan dengan penelitian serupa yang dilakukan Kartika et al penambahan larutan lidah buaya $40 \%$ dengan lama perendaman 60 menit pada Indian Mackerel (ikan kembung) selama penyimpanan suhu dingin dapat menurunkan rata-rata kadar formalin menjadi $34,08 \mathrm{mg} / 1$ dibandingkan dengan kontrol sebesar 93,29 mg/1 [9]. Penelitian Safrida et al dimana Salted Squid (cumi-cumi asin) dengan kadar konsentrasi lidah buaya $20 \%$ selama 60 menit memiliki rata-rata kadar formalin lebih rendah sebesar 1,63 $\mathrm{mg} / \mathrm{L}$ dibandingkan dengan kontrol 2,75 mg/L (Safrida, 2020).

Rata-rata kadar formalin pada ikan teri pada perlakuan dengan larutan kunyit menunjukkan kadar formalin terendah terdapat pada perlakuan dengan larutan kunyit 30\% yaitu $0,963 \mathrm{ppm}$, diikuti dengan larutan kunyit $25 \%$ dengan kadar formalin sebesar 1,215 ppm dan larutan 20\% sebesar 1,293 ppm. Hasil ini menunjukkan bahwa kadar formalin pada ikan teri berbanding terbalik dengan konsentrasi larutan kunyit yang digunakan. Hasil penelitian ini sejalan dengan penelitan Berlian menyatakan bahwa larutan konsentrasi kunyit yang paling efektif dalam menurunkan kadar formalin pada tahu putih sebesar 20\% sebesar 63\% (Berlian, 2017). Penelitian Yazid (2017) yang menyatakan bahwa larutan kunyit $7.5 \%$ dapat menurunkan kadar formalin pada white tofu (tahu putih) sebesar 62.8\%.

Penurunan kadar formalin dalam ikan teri disebabkan karena adanya senyawa saponin yang terkandung dalam media perendaman. Saponin merupakan suatu jenis glikosida yang terdapat pada tumbuhan. Cara kerja saponin dalam menurunkan kadar formalin dikenal sebagai reaksi saponifikasi atau reaksi pembentukan sabun. Zat Surfaktan atau sabun dalam saponin terdiri dari atas rantai seperti hidrokarbon yang panjang dan ion. Bagian hidrokarbon tersebut bersifat hidrofobik dapat larut dalam zat-zat non polar (minyak dan lemak) sedangkan ujung ion bersifat hidrofilik dapat larut dalam polar (air) (Rullyansyah, 2020).
Senyawa saponin teradsorpsi ke dalam daerah antar-fase dan mengikat partikel formalin untuk memperoleh stabilitas emulsi dari gugus polar. Kemampuan saponin untuk meningkatkan stabilitas emulsi tergantung pada kontribusi kelompok polar (hidrofilik) dan nonpolar (hidrofobik). Setelah formalin diikat oleh senyawa saponin, saponin akan larut dan membentuk misel. Bagian misel berinteraksi dengan air dan formalin, sehingga formalin dapat larut bersama air (Safrida, 2020).

Kandungan asam pada lidah buaya dan kunyit diduga dapat mengkatalisis proses pelepasan ikatan formalin pada protein (Kartika, 2019). Formalin berikatan dengan protein dalam bentuk methyl-alkohol yang bersifat reversible dan ikatan silang antar protein (protein-crosslink) yang bersifat irreversible (Juliadi, 2018). Ikatan methyl-alkohol akan mudah dipecah dengan adanya asam yang bertindak sebagai penyedia ion $\mathrm{H}+$. Asam dalam reaksi adisi bertindak sebagai katalis pada tahap awal protonasi oksigen. Protonasi ini akan menambah muatan positif pada karbon karbonil sehingga karbon ini lebih mudah diserang nukleofil yang lebih lemah sehingga akan melepaskan protonnya dalam air. Selanjutnya akan mengkatalis penurunan kadar formalin (Fessenden, 2010).

Hasil penelitian menunjukan bahwa kadar formalin pada ikan teri dengan perendaman larutan lidah buaya $80 \%$ lebih rendah dibandingan dengan kadar formalin pada ikan teri larutan lidah buaya $100 \%$. Hal ini terjadi karena larutan lidah buaya $80 \%$ memiliki kandungan air yang cukup untuk melarutkan kadar formalin yang telah berikatan dengan senyawa saponin. Kandungan saponin mengikat formalin dan membentuk senyawa misel. Bagian misel dapat terlarut dengan keberadaan air, sehingga kadar formalin yang diturunkan lebih efektif. Hal ini didukung dengan penelitian Safrida (2020) yang dimana senyawa saponin dapat menurunkan kadar formalin bersama dengan air. Kurangnya kandungan air pada larutan perendaman dapat menyebabkan penurunan kadar formalin yang kurang efektif. 


\section{PENUTUP}

Rata-rata kadar formalin ikan teri terendah terdapat pada kelompok larutan lidah buaya $80 \%$ sebesar 0,197 ppm dan rata-rata kadar formalin ikan teri tertinggi pada kelompok kontrol dengan 2,533 ppm.

Perlu adanya penelitian dengan mengukur kadar saponin pada larutan lidah buaya dan larutan kunyit agar keduanya memiliki kadar saponin yang sama. Peningkatkan konsentrasi lidah buaya dan kunyit hingga kadar formalin mencapai 0 ppm.

\section{DAFTAR PUSTAKA}

Ane. R..L, Soelomo. M, Teda. \& I.Y, 2016. 'Kandungan Formalin pada Ikan Asin yang dijual di Pasar tradisional Kota Makassar.' Jurnal Higieny, 2(2): 108-113.

Ariani, Novia., Maida Safutri., \& Siska Musiam., 2016, 'Analisis kualitatif formalin pada tahu mentah yang dijual di pasar kalindo, teluk tiram dan telawang Banjarmasin', Jurnal ilmiah manuntung, 2(1): 60-64.

Arisanti, Risalia Reni, Citra Indriani, Siswanto, \& Agus Wilopo., 2018, 'Kontribusi Agen dan Faktor Penyebab Kejadian Luar Biasa Keracunan Pangan di Indonesia : Kajian Sistematis.' BKM Journal of Community Medicine and Public Health., 34(3): 99-106.

Berlian, Zainal, Elfira Rosa Pane \& Sri Hartati., 2017, 'Efektivitas kunyit (Curcuma longa) sebagai pereduksi formalin pada tahu', Jurnal Sain Health, 1(1): 1-14.

Cahyadi, W, 2008, Analisis dan Aspek Kesehatan Bahan Tambahan pangan, Bumi Aksara, Jakarta.

Daniela C, H. Rusmarilin \& H. Sinaga. 2019., 'Aloe Vera and Lemon Juice Capability In Deacreasing Formaldehyde Content In Tofu Sumedang With Cold Storaging', Journal Earth and Environment Science, 260(1): 1-7.

Fessenden, R.J dan J.S Fessenden. 2010. Fundamentals of Organic Chemistry, diterjemahkan oleh Sukmariah Maun,
Kamianti Anas dan Tilda S.Sally. Tangerang:Binarupa Aksara Publisher

Juliadi, Debby., Ni Wayan Yuliasih., Dewa Ayu Ika Pramitha., \& Ni Putu Dewi Agustini., 2018, 'Uji Pengaruh Variasi Konsentrasi Perendaman Larutan asam Jawa Terhadap Penurunan Kadar Formalin Pada Sosis', Jurnal Ilmiah Medicamento, 4(2): 71-77.

Kartika, Nurul Luthfia., Evi Liviawaty., Eddy Afrianto and Iis Rostini, 2019, 'Effectiveness of Aloe vera in Reducing Formaldehyde Levels on Indian Mackerel Fish (Rastrelliger kanagurta) During Cold Temperature Storage', Asian Food Science Journal 12(1); 1-13.

Nurbaya, Siti. \& Yosi Silalahi., 2016, 'Pemeriksaan Formalin Pada Ikan Teri Asin.' Jurnal Farmanesia, 9(11):1-4.

Purawisastra, S \& Sahara, E., 2011, 'Penyerapan Formalin oleh Beberapa Jenis Bahan Makanan serta Penghilangannya Melalui Perendaman Dalam Air Panas,' Jurnal Peneliti Pusat Teknologi Terapan Kesehatan dan Epidemiologi Klinik, 31(1):63-74.

Rhomadhoni, Muslikha Nourma, Nurul Jannatul Firdausi \& Novera Herdiani, 2018, 'Tren Kejadian Keracunan Makanan Di Berbagai Wilayah Di Indonesia Tahun 2014 dan Tahun 2015'. MTPH Journal. 2(1): 51-65.

Rullyansyah, Syahrul, Fitrotin Azizah, \& Baterun Kunsah, 2020, "Pengaruh Ekstrak Lidah Buaya Dalam Mengurangi Kadar Formalin Ikan Tongkol Sebagai Makanan Halal Dan Thoyyib". Journal Of Halal Product And Research. 3(1):20-24.

Safrida Safrida, Devi Syafrianti, \& Irma Haryani, 2020, 'Effect of Aloe vera Extract in Reducing Formaldehyde in Salted Squid (Loligo indica) and Sensory Evaluation', E3S Web of Conferences 1st ICVAES 151(01037):1-3.

Syahrizal. 2016. 'Analisis kuantitatif formalin pada buah impor pada swalayan di kota banda aceh'. Jurnal action : Aceh Nutrition Journal. 1(2): 135-140.

Yazid, Edy Agustian., \& Evariza Vyanto Putri., 2017, 'Reduction Of Formaldehyde Levels In Tofu Using White Turmeric (Curcuma mango) With Spectrophotometry', Journal Islamic Pharm 2(2); 5-12. 